\author{
N.A. Esmagambet ${ }^{1,2}$, A.N. Nurpeisova ${ }^{1}$ \\ ${ }^{1}$ Scientific Research Laboratory «Robotics and Intelligent Machine», Karaganda, Kazakhstan; \\ ${ }^{2}$ Ye.A. Buketov Karaganda State University, Kazakhstan \\ (E-mail: rimlabksu@gmail.com)
}

\title{
Calculation and modeling tracked mobile robot
}

\begin{abstract}
Introduction and consideration of basic device of an unmanned ground vehicle (UGV). Determination of the most significant characteristics for exploitation of UGV allows us to formulate the main task: this is the most effective overall design. Analysis of design in the SolidWorks software package. This work in its structure relates to mechanical problems associated with the task of mechatronics. This area of research in mechatronics today is an actual and rapidly developing discipline. More precisely we can attribute the tasks discussed in this article to the description of modular unmanned ground robot with manual control.
\end{abstract}

Keywords: ground vehicle, caterpillar platform, calculation of electric motor, SolidWorks, hull, layout.9.

\section{Introduction}

Mechanisms and machines are an inseparable part of human life. The development of this field has led to the creation of a complex and organized system of mechanisms interaction between themselves and environment. For example, mechatronics, that was established in the 30-ies of twentieth century. Mechatronics combines mechanics, electronics, designing (the main tool is the CAD system (computer-aided design)), programming. Mechatronics allows us to answer the question: which construct of ground design is the most optimal and effective for exploitation under different environmental conditions. The main research tool is the CAD software SolidWorks. The SolidWorks software package opens up wide opportunities for research. SolidWorks allows us to design three-dimensional objects, collecting them in an assembly of a certain construction. By means of extra addittions such as SolidWorks Motion or SolidWorks Simulation, we can analyse design in a software-recreated reality that is as close as possible to the required conditions.

\section{Layout}

The layout of the UGV is a functionally conditioned location of motor-transmission installation, power supply, chassis, UGV systems and auxiliary equipment [1]. The layout can be general and private. General layout determines relative positioning of robot's elements, i.e. outlines how device will look. Private layout defines the device and appearance of individual robot's elements. The main task of the layout is to obtain the most efficient design for given conditions. The best scheme of general layout of the ground vehicle has several features:

- minimum unused internal volumes;

- the shortest way of transferring energy from engine to moving parts of machine.

Generally, ground vehicle on a caterpillar platform basically have same design, i.e. body, caterpillar prop, which consists of a driving wheel, track rollers, sloth, balancers and, optionally, supporting rollers, suspension, transmission and complementary modules, motors and mechanical connections between the elements.

\section{Hull}

The hull [2] is the basic component of caterpillar platform. Optimally selected body provides the most favourable location of propulsion unit, internal components and additional modules, as well as convenient access to the components. There are various forms of device hull, each of which has its own characteristics (Picture 1). 

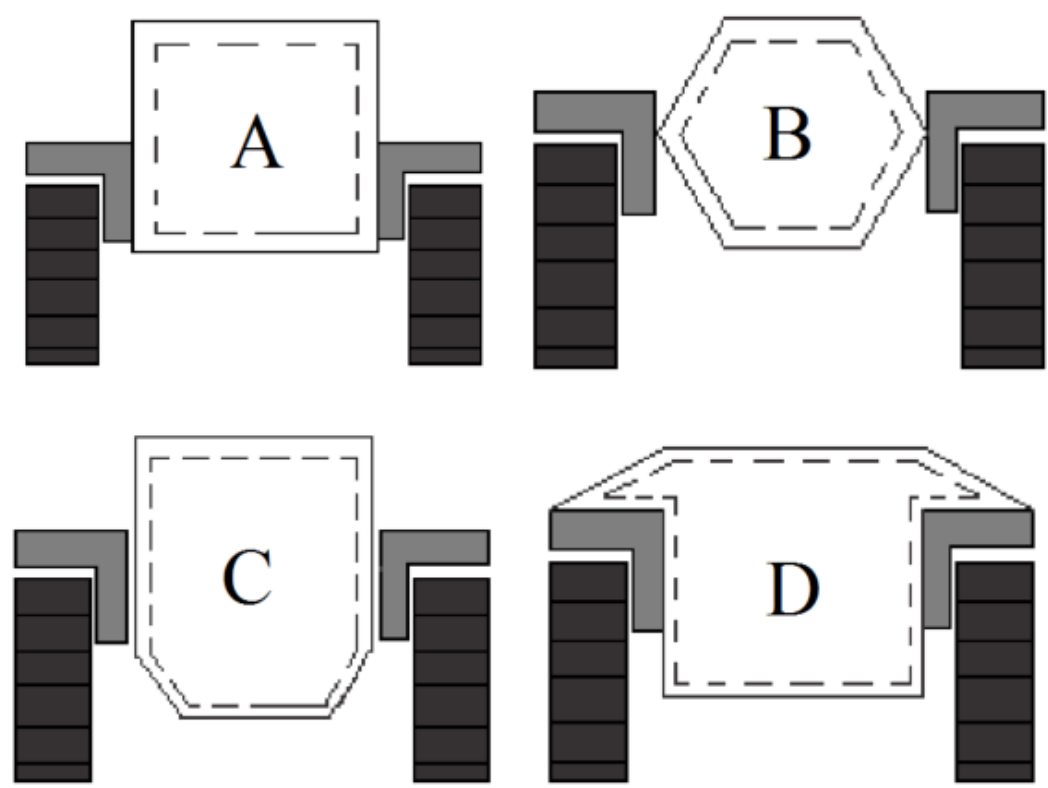

Picture 1. Forms of the cross sections of hulls

The selection of material usually comes from relations price-quality (strength) -mass and from purposes of appointment. Used materials can be divided into groups: metallic, non-metallic and combined. From metal materials mainly used steel, aluminium. And from non-metallic - wood, fiberglass, plastic, HPL - panel, etc.

In the existing design were used HPL panels that were made of wood fibers that were pressed at high temperature and pressure. Choice of this material was the most optimal by criteria of price and weight (see Chart).

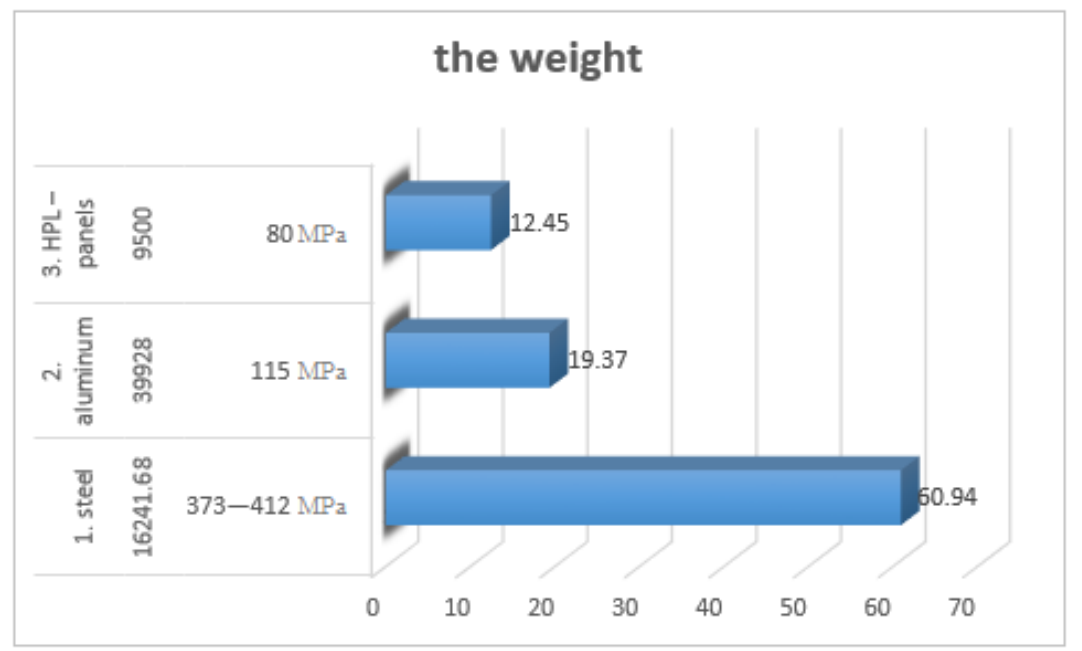

Chart. Comparative chart by price criteria - quality (strength) - weight

Transmission and engine installation

Transmission (powertrain) - a set of mechanisms that match engine with its propulsion, as well as systems that ensure work of mechanisms. Transmission is responsible for changing traction effort, speed and direction of motion.

The main requirements for transmission:

- Providing high traction and speed;

- Simplicity and easeness of management; 
- High reliability of work over a long period of exploitation;

- Small mass and overall dimensions of mechanisms;

- Simplicity of production;

- Convenience in maintenance during exploitation and repair.

In ground mobile platforms mechanical transmissions are predominantly used. On such mobile bases, the transmission elements are: a reducer, a chain connecting motor to shaft on which driving wheel is located, a system of asterisks connecting chain to shaft.

The main component leading robot into motion is the drive. It includes an engine and devices that regulate engine. Drives must provide a constant engine speed with variable load, a constant torque on motor shaft, high precision of the components system included in the engine and much more. The drive significantly determines structure, parameters and technological parameters of the robot. Main characteristics of the drive are: power, velocity and performance of system, sensitivity to the control signal.

Drives are systematized according to type of engine, their number, availability and type of transfer devices. At present time are used electric, hydraulic, pneumatic and other drives.

The main characteristics of electric motor are:

Electrical:

- Voltage Range (Recommended) is permissible range of supply voltages. The higher supply voltage, the greater motor power and velocity of rotation. But if a certain voltage value is exceeded, motor will fail.

- Voltage (Nominal) is optimum voltage at which motor is able to rotate quickly and not overheat while doing that.

- No-load current is current that motor consumes at idle.

- Stall current is current that motor consumes when shaft is blocked.

Mechanical:

- Shaft diameter is diameter of moving axis of the engine making movement.

- Velocity without load is velocity of rotation of motor shaft (number of revolutions per minute) at idle.

- Moment of force (torque) is a vector physical quantity that characterizes rotational action of force on a solid body.

Motor has one of the significant characteristics, by quantity of which we can determine whether engine can pull the robot, this is the moment of force. The engines for terrestrial vehicle were chosen according to the power and thrust criteria. External DC collector motor, with integrated reducer, on permanent magnets, is designed for connection any single-speed bicycles to the rear wheel, as well as for conversion to electric traction of other vehicles: scooters, skateboards, wheelchairs, etc.

Specifications:

- Voltage (nominal) 24 volts.

- Power (nominal): 250 watts.

- Maximum power: 270 watts.

- Maximum efficiency of the wheel motor: $82.5 \%$.

- Maximum rpm: 360.

- The maximum velocity of an electric bike with an installed external DC collector motor depends on the diameter of rim and is usually $18-25 \mathrm{~km} / \mathrm{h}$.

- Gear ratios: 9:62.

- 4 brushes 5.5x6 mm.

- Sprocket on 12-tooth.

- Hull: aluminium alloy.

- Overall dimensions: 130 x 102 x 134 mm.

- Weight: $2.2 \mathrm{~kg}$.

- Length of power wires: $0.5 \mathrm{~m}$.

- operational temperature: $-25 \mathrm{C}^{0} /+45 \mathrm{C}^{0}$.

So, we calculate power and moment of force of robot motor with a weight of $70 \mathrm{~kg}$, maximum speed of which is $2 \mathrm{~m} / \mathrm{s}$ and the radius of driving wheels is $0,075 \mathrm{~m}$.

First we need to calculate the acceleration:

$$
v^{2}=v_{0}^{2}+2 \cdot a \cdot s \Rightarrow a=\frac{v^{2}-v_{0}^{2}}{2 s},
$$


where $s$ is distance overcome by robot, $a$ is acceleration, $v_{0}$ is initial velocity:

$$
a=\frac{2-0}{2 \cdot 5}=\frac{2}{10}=0.2 \mathrm{~m} / \mathrm{s}^{2} .
$$

Using the basic equation of rotational motion's dynamics, we find the moment of force:

$$
M=I \cdot \epsilon, I=\frac{m \cdot g \cdot r^{2}}{2} \Rightarrow M=\frac{m \cdot g \cdot r \cdot a}{2}, \epsilon=\frac{a}{r} .
$$

$I$ is moment of inertia, $\epsilon$ is angular acceleration, $g$ is acceleration of gravity $(10 \mathrm{~m} / \mathrm{s}), r$ is wheel radius, $m$ is the mass of entire robot:

$$
M=\frac{70 \cdot 10 \cdot 0.075 \cdot 0.2}{2}=5.25 \mathrm{~N} / \mathrm{m} .
$$

The resulting torque is distributed between robot's motors, and it must be divided into the gear ratio of transmission used.

Power required by engine is determined by formula:

$$
P=M \cdot \omega,
$$

$\omega$ is angular velocity.

$$
\omega=\frac{v}{r} \Rightarrow P=M \cdot \frac{v}{r} \Rightarrow P=5.25 \cdot \frac{2}{0.075}=140 \mathrm{~W} .
$$

\section{Mechanical connections and parts of the device}

Mechanical connections and parts include: split and integral connections, shafts, various fastenings and supports, bearings and etc [3].

Connections are process of assembling a product from parts, assemblies, aggregates into a unit, holistic mechanism. Connections can be separable, allowing disassembly of elements with subsequent restoration and all-in-one, allowing analysis only under full or partial destruction.

The shaft Table is a part of mechanism that supports rotating components of mechanism and transmitting torque. The axis is a detail of mechanism that does not directly participate in transmission of motion.

Table

\section{Common types of shafts}

\begin{tabular}{|c|c|}
\hline Sign of shaft & Scheme \\
\hline Smooth & \\
\hline Stepped & \\
\hline Crank & \\
\hline Kneed & \\
\hline Cam & \\
\hline
\end{tabular}

Chassis

Chassis of platform is divided into a caterpillar prop and a suspension. The term «undercarriage» can also be used.

Movement of the tank realises by means of a caterpillar mover consisting of caterpillars and associated devices: footing and supporting rollers, driving and guiding (idler) wheel, a device for pulling caterpillars. The suspension is composed of components that connect platform hull to axes of its support rollers. Suspension includes springs, balancers and shock absorbers.

The caterpillar mover is a propulsion device, in which a pulling force is created by rewinding the belt. Mover is a set of devices interacting with the external environment and creating an external traction force. In general case, caterpillar mover consists of a driving wheel, footing rollers, supporting wheels, guiding wheels (idler) and a caterpillar belt. 
Under the action of torque $\mathrm{M}$, the driving wheels begin to rewind caterpillar belt, which create rail tracks for machine and with the help of footing rollers the carrier system of machine moves along them (Picture 2). The next component of chassis is the suspension.
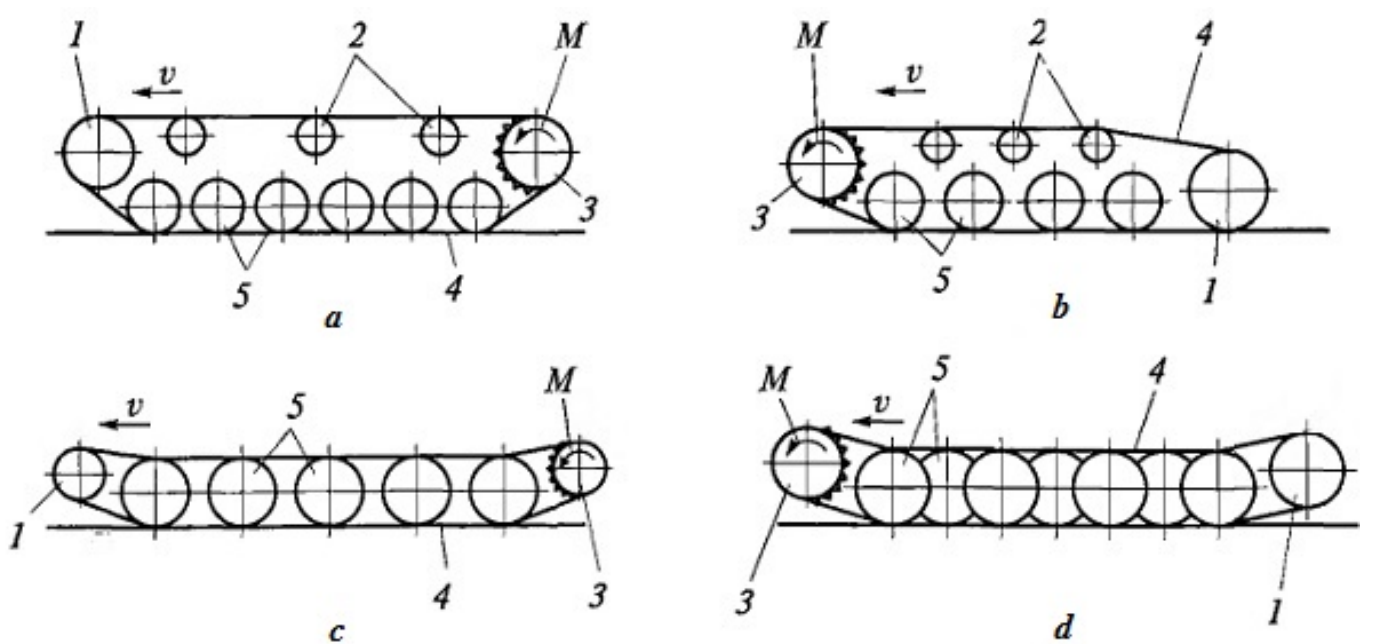

1 - is idler; 2 - are supporting wheels (rollers); 3 - is the driving wheel; 4 - is caterpillar tape; 5 - are footing rollers; $v$ - is velocity; $M-$ is the torque

Picture 2. Scheme of caterpillar propulsors with rear $(\mathrm{a}, \mathrm{b})$ and front $(\mathrm{c}, \mathrm{d})$ arrangement of the driving wheel

Suspension is a collection of units, parts and mechanisms that connect robot body on a caterpillar platform by means of axis of footing rollers. In general case each suspension's assembly includes an elastic element (spring), a shock absorber (damper), and a balancer.

Static stroke of roller is movement of footing roller vertically from position of fully unloaded elastic element to the position of its loading under weight of the robot.

Dynamic stroke of roller is movement of footing roller vertically from static position to the stop in the limiter of roller.

Full stroke of roller is movement of footing roller vertically from position of fully unloaded footing element to the stop in the limiter of roller, is defined as the sum of static and dynamic strokes of roller.

A number of the following requirements are put forward to the suspension:

- ensuring maximum smoothness of the stroke under various road and ground conditions;

- have high reliability at various loads;

- the most convenient maintenance and repair, easy to install and dismantle.

In addition to mechanical part of the robot there is electronic one, which includes power and control. Thanks to battery, the robot becomes «alive». And can perform its functions for some time.

So, what is a battery? The battery (Lat. Collector) is a device that stores energy for its further use. It is a device inside of which occurs a chemical reaction, during which an electric charge is produced.

Let's highlight the main characteristics of batteries:

- Construction (hull);

- electrochemical system;

- voltage;

- capacity;

- internal resistance;

- self-discharge current;

- life time.

Next significant part of the mobile robot is information management system (IMS) [4]. The IMS pursues a number of aims, such that:

a) Transformation and perception of information about environment, as well as about the robot itself;

b) Based on the control program, command signals from control panel and information about state of the robot and environment, development of the laws of executive device's motion; 
c) Transmission of signals to actuators and mechanisms of the executive system for purpose of robot's interaction with environment. In the base of the information management system is the management system (MS), information and measurement system (IMS) and communication system (CS). Determination of robot functions' number mostly depends from its information management system, such as flexibility, positioning accuracy, speed.

\section{Modeling mobile robot in CAD SolidWorks}

SolidWorks is said to be software complex CAD for works automation of an industrial enterprise at stages of design and technological preparation of production. It provides products development of any complexity and purpose. It works in a Microsoft Windows environment (Picture 3).

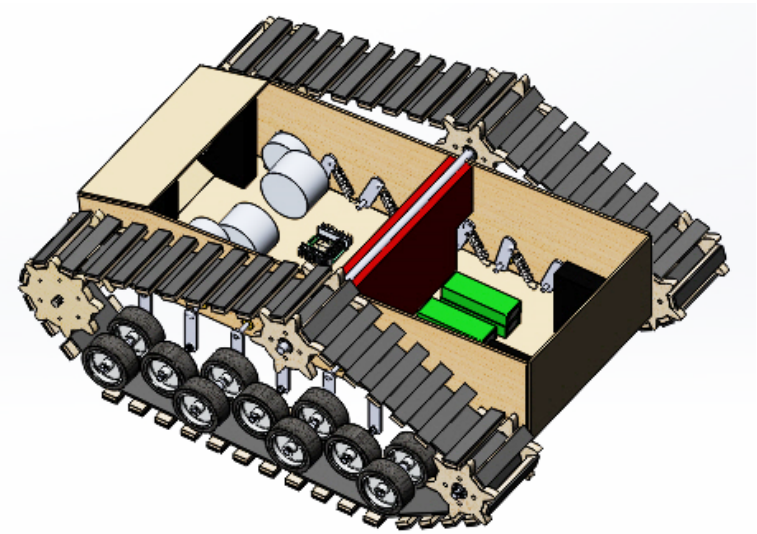

Picture 3. Building a ground robot model

The very first step before creating a model is choosing the plane: right, front or top. Then, we can make a sketch of the future 3D model, which is stretching out into solid body by «Piglet» tool. Sketch consists of tools such as - circle, segments, splines, arrays, rectangle, line and much more.

In order to build a model of the hull, we must recreate model of each its parts, which in turn combined into assemblies. And assemblies develop by combining into even greater, a complex assembly.

We created the hull model in several stages. First, we constructed separate components, such as armor of the hull, consisting of a front top plate, a front middle and lower armored plates, a bottom, a rear armor plate and side armor plates, driving wheels, shafts, sloths, rockers, support wheels. Which, subsequently, we combined into one complex assembly

We interconnected the armored plates when using tools such as «Object Conversion», «Object Shift», «Move Objects».

Hull's omplex assembly requires careful work, powerful support equipment, as well as software that is able to provide stable operation of the program SolidWorks.

\section{References}

1 Чобиток В.А. Конструкция и расчёт танков и БМП: учебник / В.А. Чобиток, Ю.Н. Брижинёв, А.А. Долганов, капитан А.В. Мирошник. - М.: Военное изд-во, 1984.

2 Антонов А.С. Танк: книга / А.С. Антонов, Б.А. Артамонов, Б.М. Коробков, Е.И. Магидович. - М.: Военное изд-во МО СССР, 1954.

3 Горбатюк С.М. Детали машин и основы конструирования: учебник / С.М. Горбатюк и др.; под ред. С.М. Горбатюка. - М.: Изд. Дом МИСиС, 2014.

4 Василенко Н.В. Основы робототехники / Н.В. Василенко, К.Д. Никитин, В.П. Пономарёв, А.Ю. Смолин; под ред. К.Д. Никитина. - Томск: МГП «Раско», 1993. 
Н.А. Есмағамбет, А.Н. Нурпеисова

\title{
Шынжыр табан платформасындағы ұтқыр роботты есептеу және модельдеу
}

\begin{abstract}
Мақалада пилотсыз жерүсті аппаратының (ПЖА) негізгі құрылғылары қарастырылған. Ең маңызды белгілері анықталып, ПЖА пайдалану үшін басты міндет қалыптастыруға мүмкіндік береді, яғни барынша тиімді жалпы құрылым табуға. Авторлармен конструкциялар SolidWorks бағдарламалық кешенінде талданды. Бұл жұмыс құрылымы бойынша мехатрониканың міндеттерімен байланысты механика мәселелеріне жатады. Берілген зерттеу сапасы бүгінгі таңдауы мехатроникадағы өзекті және жылдам дамылып келе жатқан пән болып есептеледі. Дәлірек айтқанда, осы мақалада қаралған мәселелерді қолмен басқарылатын модульді жерүсті роботтың сипаттамасына жатқызуға болады.
\end{abstract}

Kiлm сөздер: жерүсті аппарат, шынжыр табанды алаңы, электрқозғалтқыш есептеу, SolidWorks, симуляция, құрастыру.

\author{
Н.А. Есмағамбет, А.Н. Нурпеисова
}

\section{Расчёт и моделирование мобильного робота на гусеничной платформе}

В статье рассмотрено основное устройство беспилотного наземного аппарата (БПНА). Определены наиболее значимые признаки для эксплуатации БПНА, позволяющие сформулировать главную задачу - максимально эффективную общую конструкцию. Авторами проанализирована конструкция в программном комплексе SolidWorks. Данная работа по своей структуре имеет отношение к проблемам механики, связанным с задачами мехатроники. Данная область исследований в мехатронике на сегодняшний день является актуальной и быстро развивающейся дисциплиной. Более точно задачи, рассмотренные в данной статье, можно отнести к описанию модульного беспилотного наземного робота с ручным управлением.

Ключевые слова: наземный аппарат, гусеничная платформа, расчёт электродвигателя, SolidWorks, симуляция, компоновка.

\section{References}

1 Chobitok, V.A., Brizhinov, Yu.N., Dolganov, A.A., \& captain Miroshnik, A.V. (1984). Konstruktsiia $i$ raschet tankov $i$ BMP [Design and calculation of tanks and infantry fighting vehicles]. Moscow [in Russian].

2 Antonov, A.S., Artamonov, B.A., Korobkov, B.M., \& Magidovich, E.I. (1954). Tank [Tank]. Moscow: Voennoe izdatelstvo MO SSSR [in Russian].

3 Gorbatyuk, S.M. \& et al. (2014). Detali mashin i osnovy konstruirovaniia [Machine parts and design basics]. S.M. Gorbatyuk (Ed.). Moscow: Izdatelskii Dom MISiS [in Russian].

4 Vasilenko, N.V., Nikitin, K.D., Ponomarev, V.P., \& Smolin, A.Yu. (1993). Osnovy robototehniki [Basics of Robotics]. K.D. Nikitin (Ed.). Tomsk: MHP «Rasko» [in Russian]. 